\title{
A pozitív élmények feldolgozásának (savoring) jelentoosége a daganatos megbetegedések komplex terápiájában
}

\author{
PÁLINKÓNÉ VÁRSZEGI ANDREA ${ }^{1 *}$ - F. LASSÚ ZSUZSA² \\ ${ }^{1}$ ELTE Eötvös Loránd Tudományegyetem Pedagógiai és Pszichológiai Kar \\ Pszichológiai Doktori Iskola, Budapest \\ ${ }^{2}$ ELTE Eötvös Loránd Tudományegyetem Tanító- és Óvóképző Kar, Budapest
}

(Beérkezett: 2020. január 5.; elfogadva: 2020. május 19.)

\begin{abstract}
A témában megjelenő friss kutatási eredmények összefoglalásával arra kerestük a választ, hogy a pozitív élmények feldolgozása (savoring) milyen jelentőséggel bír a daganatos megbetegedések komplex terápiájában. Az eredmények azt mutatják, hogy a savoring nem csak a boldog élet egyik nélkülözhetetlen összetevője. Azokban a stresszel teli időszakokban is fontos erőforrásként szolgálhat - mind a páciens, mind pedig az ót ápoló hozzátartozók életében is -, mint amilyet az életet veszélyeztető, daganatos betegségek is jelentenek. A pozitív tapasztalások „ízlelgetése” képes csökkenteni a megbetegedéssel kapcsolatos szorongásos és depresszív tüneteket, az érzelmi distresszt, valamint növelni a pozitív érzelmi állapotot, és az élettel és párkapcsolattal való elégedettséget is. Az említésre kerülő eredmények, valamint savoring intervenciós lehetőségek akár a hazai onkopszichológiai ellátás területén is új színfoltot jelenthetnek.
\end{abstract}

Kulcsszavak: savoring, pozitív érzelem, daganatos megbetegedés, intervenció

\section{Bevezetés}

A Fred B. Bryant (1989) nevéhez fúződő savoring jelenségének kutatása egyre nagyobb teret kap a pozitív érzelmek szabályozásának területén (Garland, Farb, Goldin, \& Fredrickson, 2015a; Quoidbach, Berry, Hansenne, \& Mikolajczak, 2010; Tugade \& Fredrickson, 2007). Jelentősége nemcsak az átlagpopuláció mindennapjaiban mutatkozik meg, de egyre növekszik a klinikai mintán végzett kutatási eredmények száma is (Carl, Soskin, Kerns, \& Barlow, 2013). A jelenleg igen szúk körú irodalmi adatok áttekintésével arra keressük a választ, hogy hogyan mutatkozik meg a pozitív élmények megélésének (savoring) jelentősége daganatos betegségek esetén.

\footnotetext{
* Levelező szerzó: dr. Pálinkóné Várszegi Andrea, H-1097 Budapest, Ecseri út 3. B/101. E-mail: andrea.varszegi@gmail.com
} 


\subsection{A savoring fogalma és jellegzetességei}

A savoring kifejezés az angol „savor” szóból, a latin „sapere” terminusból ered, amelynek jelentése: ízlelni, jó ízúnek, illetve bölcsnek lenni, németül: bewusst genießen, azaz tudatosan ízlelni, élvezni. A magyar nyelvben a savoring jelentésének megragadására az „ízlelgetés” szót vagy a „pozitív élmények feldolgozása" kifejezést használjuk (Szondy, Martos, Szabó-Bartha, \& Pünkösty, 2014). Az elnevezés azt a dinamikus folyamatot fejezi ki, amely a pillanat észlelése és az ehhez kapcsolódó pozitív érzelmek tudatos fenntartása és fokozása közben megy végbe, a pusztán érzéki megtapasztaláson túlmenően (Blickhan, 2015; Bryant \& Veroff, 2007). A savoring tehát nem más, mint a pozitív érzelmek felett észlelt kontroll, amely során a személy képes akaratlagosan generálni, erősíteni és meghosszabbítani a pozitív eseményból származó élvezetet (Bryant, 2003). Az említett konstruktum állapot- és vonásjellegú változóként is felfogható, ahol az elóbb említett egy állapothoz kötött reakcióként, az utóbbi pedig állandó személyiségvonásként tekinthetó (Jose, Lim, \& Bryant, 2012).

A pozitív élmények feldolgozása - az idői perspektíva tekintetében - irányulhat a jelen pillanatra, a jövőre (álmodozás, tervezgetés) és a múltra (felidézés) egyaránt (Bryant, 2003). A pozitív élmények élvezetére vonatkozó hiedelmeink mérésére a Savoring Beliefs Inventory (SBI) elnevezésú mérőeszközt alkalmazzák (Bryant, 2003; más nyelveken ld. Metin-Orta, 2018; Robles és mtsai, 2011). Az említett leltár azt méri, hogy a személy - saját elképzelése szerint -, milyen mértékben képes a pozitív élmények megélésére.

A savoring folyamata három lépésból áll. (1) A legalapvetőbb szinten a szervezetünket érő pozitív ingerek megtapasztalása szükséges. (2) Ezt követően megindulhat maga az ízlelgetés, amely során figyelmünket az ingerre és az ehhez kapcsolódó pozitív érzésre irányítjuk. (3) Harmadszorra pedig valamilyen stratégiát alkalmazva (pl. az élmény megosztása másokkal) válaszolhatunk a kiváltott érzelmekre, amely adaptív volta esetén a folyamatot visszacsatolja és egy önmagát megerősítő felfelé mutató spirál indulhat meg (Bryant \& Veroff, 2007).

Bryant és Veroff (2007) tíz savoring stratégiát különböztetett meg. Ezek közül hat kognitív: (1) az emlék kialakítása, (2) ön-gratuláció (amely során a személy kinyilvánítja önmaga számára, hogy büszke magára), (3) összehasonlítás, (4) szenzoros-észlelési „kiélesedés”, (5) idői tudatosság, (6) hálaérzés; három viselkedéses: (7) az élmény megosztása másokkal, (8) a pozitív érzelmi állapot viselkedéses kifejezése, (9) feloldódás (amely során a személy hagyja, hogy elárasszák a pozitív tapasztalások, anélkül, hogy azokra kognitívan reflektálna); és egy szintén kognitív, ám a pozitív érzelmeket inkább csökkentő folyamat: (10) az „örömgyilkos” gondolatok (amelyek a 
pozitív tapasztalások élvezetét csökkentik, például olyan gondolatokon keresztül, hogy a személy nem is érdemli meg azt a jót, ami történik vele) (Bryant \& Veroff, 2007; Chadwick, 2012; Szondy és mtsai, 2014).

A savoring stratégiák mérésére a Pozitív Élmények Feldolgozási Módjai Skála (Abridged Ways of Savoring Checklist; Bryant \& Veroff, 2007) használható, amely a személy pozitív élményekre adott kognitív és viselkedéses válaszát térképezi fel. A skála magyar adaptációját ld. Szondy és munkatársai (2014) tanulmányában.

Mivel nem minden pozitív élményre adott reakció növeli a pozitív érzéseket, az alkalmazott savoring stratégia alapvetően meghatározza a pozitív élmény ízlelgetésének végkimenetelét. Az eredetileg leírt 10 savoring stratégia (Bryant \& Veroff, 2007) - a magyar vizsgálat eredményei alapján is (Szondy és mtsai, 2014) - két fő csoportba rendezhető: a pozitív élményekbe bevonódó ( $\mathrm{pl}$. feloldódás) és a pozitív élményektől eltávolodó élményfeldolgozás (úgymint örömgyilkos gondolatok) kategóriájába. Az eltávolodó élményfeldolgozási stratégia eredményét tekintve épp ellentétes hatású, mint a bevonódó stratégia, hiszen az előbbi esetben az élmény átélése által nyújtott pozitív érzést a személy tompítja, ahelyett, hogy bevonódó stratégiát alkalmazva fokozná annak hatását a savoring pozitív végkimenetelének elérése érdekében. A kutatási eredmények azt mutatják, hogy a legmagasabb boldogságszint azoknál a személyeknél mérhető, akik a savoring stratégiák szélesebb palettájával rendelkeznek és a különböző szituációkban képesek ezek adekvát változatainak bevetésére (Quoidbach és mtsai, 2010).

\subsection{A savoring funkciója \\ a stresszel való megküzdés vonatkozásában}

A mentális egészség irodalmában korábban nagyobb hangsúlyt kapott a stresszel való megküzdés tanulmányozása, amely elsősorban a distressz negatív testi-lelki hatásai csökkentésének lehetőségeit tárta fel (ld. pl. Friedman és mtsai, 1992; Park, Edmondson, Fenster, \& Blank, 2008). A jóllét jelenségének holisztikus vizsgálatához szükségünk van azonban annak figyelembe vételére is, hogy az életünk során minket érő pozitív behatásokat hogyan dolgozzuk fel (Bryant \& Veroff, 2007). Egészséges populáción végzett vizsgálatok kimutatták, hogy a savoring mediálja a kapcsolatot a reziliencia és a mentális egészség között. A pozitív élmények ízlelgetésére való erősebb képesség segíthet a kognitív és viselkedéses repertoárunk bővítésében, amely - a személyes erőforrások növekedése által - rezilienciánkat növeli, magyarázva a kapcsolatot a pszichológiai rugalmasság és a mentális egészség között (Wilson \& Saklofske, 2018). Időseken végzett vizsgá- 
latokban szintén kimutatták, hogy a pozitív élmények ízlelgetésére való magasabb képesség nagyobb boldogságot és magasabb élettel való elégedettséget jelez elöre (Smith \& Hollinger-Smith, 2015).

A hagyományos értelemben vett megküzdési képesség, az egyén azon törekvéseit mutatja, amelyekkel az erőforrásait fenyegető stresszkeltó ingerekkel igyekszik megbirkózni vagy azokhoz alkalmazkodni (Lazarus \& Folkman 1984). Nelson és Simmons (2002) holisztikus stressz modellje alapján, az egyént éró ingerek nemcsak negatív (distressz), hanem pozitív, úgynevezett eustresszt is kiválthatnak. Míg az elóbbivel coping stratégiáink segítségével tudunk megküzdeni, addig az utóbbihoz savoring stratégiáinkat alkalmazzuk. Ebben a felfogásban tehát a savoring és a coping két egymástól elkülöníthető független folyamat, ahol a savoring a coping pozitív párjaként értelmezhető (Nelson \& Simmons, 2002). Az, hogy valaki megfelelő coping stratégiákkal rendelkezik az ôt ért negatív stresszel való megküzdésre, még nem jelenti azt, hogy képes adaptív savoring stratégiákat alkalmazni a pozitív élmények megélésére, illetve hatásuk kiaknázására (Bryant, 1989).

Az újabb kutatások eredményei arra is felhívják a figyelmet, hogy a stresszes események során nem csak észleljük az alkalmazott savoring stratégiáinkat, de hajlamosak vagyunk intenzívebben használni azokat, hogy védelmet nyújtsanak a nehéz élethelyzetekhez való alkalmazkodás során (Monteiro \& Marques Pinto, 2017; Samios \& Khatri, 2019), vagyis a savoring felfogható egyfajta megküzdésként is, amely segít enyhíteni a distressz káros hatását (Samios \& Khatri, 2019).

Az érzelemszabályozás hagyományos definíciója alapján minden olyan folyamatot ennek részeként tekintünk, amivel az egyén szabályozni képes érzelmeinek mértékét és időbeliségét, valamint ezek megtapasztalását és kifejezését (Gross, 1998). A tágan vett definíció alapján minden megküzdési próbálkozást tekinthetünk egyfajta érzelemszabályozásként is (Garnefski, 2001; Gross, 1998). Így a savoring folyamatát, ahol az emberek előidézik, értékelik és fokozzák a pozitív tapasztalásaikat (Bryant \& Veroff, 2007), a pozitív érzelemszabályozás egyik formájaként is felfoghatjuk (Samios \& Khatri, 2019).

\section{A daganatos megbetegedés, mint stresszteli életesemény}

Akárcsak a természeti katasztrófák vagy váratlan balesetek elszenvedői, a daganatos betegek a diagnózis hallatán az életük feletti kontroll elvesztését élhetik át és számos félelem aktiválódhat. Ezek közül a leggyakoribbak a halálfélelem, a függetlenség elvesztésétől, a mútétektől, a kezelésektől és 
a fájdalomtól való félelem. Nehézséget jelenthet a betegséghez, a különböző szakemberekhez, a környezethez és az állandó bizonytalansághoz való folyamatos alkalmazkodás is (Horti \& Riskó, 2017). Bár a daganatos betegségek több ponton különböznek más traumatikus élethelyzetektől (pl. a stresszor belső fenyegetettséget jelent, tartalmában komplexebb, hosszabb időn át fennállhat és magában foglalja egy jövőbeni visszaesés lehetőségét is), mégis találunk olyan alapvető egyezéseket, amelyek megerősítik a krónikusan fennálló daganatos betegségról, mint traumáról való gondolkodás megalapozottságát (Cordova és mtsai, 2007; Zsigmond, Rigó, \& Bányai, 2017). Ilyen lehet a halállal való szembesülés, a világba vetett hit és a kialakult vonatkoztatási rendszer megingása, amely erős kiszolgáltatottságérzést eredményezhet, kontrollvesztéssel és tehetetlenséggel párosulhat (Zsigmond és mtsai, 2017). Ezek a helyzetek is meghaladják tehát az ember mindennapi alkalmazkodó képességét és fenyegetik testi-lelki integritását (Hermann, 2003; Pohárnok \& Lénárd, 2015). Érthető így, hogy az életet veszélyeztetó állapotok a legtöbb személynél olyan mértékú stresszt válthatnak ki, amely akár még poszttraumás stresszbetegséget (PTSD) is okozhat (Cordova és mtsai, 2007).

A PTSD és a savoring kapcsolatát még nem vizsgálták a rákos megbetegedések vonatkozásában, azonban talán nemcsak szimbolikusan, hanem egészségpszichológiai szempontból is használhatjuk a rákkal való küzdelemre a harctér metaforáját (Skott, 2002). Harcból visszatérő katonáknál vizsgálva a PTSD és a savoring összefüggését azt találták, hogy minél erősebb a személy pozitív élmények élvezetére vonatkozó hiedelme, annál alacsonyabb fokban jelennek meg a depresszió és a poszttraumás stressz zavar tünetei. Ezen felül úgy túnik, hogy a savoring képes mérsékelni a kapcsolatot a harcnak való kitettség és a fentebb említett PTSD-s és depresszív tünetek megjelenése között (Sytine, Britt, Pury, \& Rosopa, 2018).

A daganatos megbetegedés, mint életet veszélyeztetó állapot és az azzal való megküzdés azonban lehetóséget adhat arra is, hogy a beteg átgondolja az életét, hogy másképp lásson dolgokat és azt, hogy mi fontos, értékes és mi nem. Az életben szerzett tapasztalatok új jelentést kaphatnak és a megélés újabb formái kerülhetnek kialakításra (Kruse, 1999). Mindez akár a poszttraumás növekedéshez is hozzájárulhat (Cordova és mtsai, 2007), amikor az egyén a traumát nem pusztán túléli, hanem annak hatására olyan pozitív változásokon megy keresztül, amelyek aztán a krízist megelőzó állapothoz képest magasabb fokú múködéshez vezetnek élete bizonyos területein (Tedeschi \& Calhoun, 2004). Ez utóbbi állapot elérésében segíthet, ha a beteg figyelmi fókusza a fontos erőforrásokon, illetve a daganatos betegséggel kapcsolatban megélt pozitív tapasztalatokon és nem pedig a kontrollálhatatlan és megoldhatatlan problémákon van (Chan, Ho, Tedeschi, \& Leung, 2011). 


\section{A savoring jelentósége a daganatos megbetegedésekben}

A fentebb említett vizsgálatok eredményei alapján látható, hogy a negatív, életet veszélyeztetó események kapcsán nem csak az azokkal való megküzdési képességeink megléte és milyensége számít. Fontos, hogy ezekben a helyzetekben milyen eróforrásokat tudunk mozgósítani, amelyek közé a pozitív élmények (történjenek ezek velünk a jelenben, a múltban vagy akár a jövóben) élvezete is besorolható.

Érthetó tehát annak fontossága, hogy a savoringgel kapcsolatos kutatások egyre szélesebb körben terjednek ki klinikai populációra és így különböző daganatos megbetegedéssel diagnosztizált személyek vizsgálatára is. Kemoterápiában részesülő pácienseknél is azt találták, hogy a pozitív élmények magasabb szintú ízlelgetése/feldolgozása jobb életminőséggel és - a betegség viszontagságai ellenére - kevesebb érzelmi distresszel jár (Garland, 2016).

Hou és munkatársai (2016) 263 daganatos betegségben (tüdő-, vastagbél-, végbél-, gyomor- és májrákban) szenvedő pácienst vizsgáltak. Azt találták, hogy minél súlyosabb fizikai tüneteket okoz a páciens számára a betegsége, annál magasabb szorongásszintet és annál erősebb depresszív tüneteket mutat, illetve annál alacsonyabb a pozitív érzelemszintje és annál kevésbé elégedett életével. Jelentős kapcsolatot találtak ugyanakkor a pozitív élmények ízlelgetésére való magasabb képesség, és a fizikai tünetek, a szorongás és a depresszió alacsonyabb, valamint a pozitív érzelmek megléte és az élettel való elégedettség magasabb szintje között is. Eredményeik azt mutatják, hogy azoknál a személyeknél, akik a savoring magas szintjéről számoltak be önmagukkal kapcsolatban, nem volt szignifikáns kapcsolat a betegség által okozott fizikai tünetek és a depresszív tünetek kialakulása között, míg a savoringre való alacsonyabb képesség esetén ez a kapcsolat szignifikáns volt. Hasonlóan tehát a korábban említett, katonákon végzett vizsgálatok eredményéhez (Sytine és mtsai, 2018), a pozitív élmények megélésének fokozására való képesség mérsékelheti a betegség által okozott fizikai tünetek és a megjelenő depresszív tünetek közötti kapcsolatot (Hou és mtsai, 2016).

\section{A savoring jelentôsége a páciens és az ót támogató környezet számára}

További vizsgálatokban alátámasztást nyert, hogy a pozitív élmények megélésének és az általuk nyújtott erőforrások kiaknázásának képessége fontos védőforrás lehet a betegségben érintett családi rendszer számára is, hiszen 
ezek a nehéz helyzetek nemcsak a páciens életére vannak hatással, hanem kivetik árnyékukat a legszorosabb szociális kapcsolatokra, a beteget ápoló családtagokra is.

Samios és Khatri (2019) 128 ausztrál - különböző nemú - párt vizsgált, akik az elmúlt években valamilyen stresszel teli életeseményen estek át. Eredményeik kiértékelését a hazánkban még kevéssé ismert, ún. szereplöpartner egymásrautaltsági modell (Actor-Partner Interdependence Model; Vajda \& Rózsa, 2018) segítségével végezték, amely lehetővé tette a diádikus - vagyis két személy párosára vonatkozó - adatelemzést. Alapvetésük szerint a stresszor hatása, amely a pár egyik tagját érinti, a pár másik tagjára is hatással van. Eredményeik magas interkorrelációt mutatnak a pár tagjainak három idői síkra (múltra, jelenre és jövőre) irányuló savoringje között, ami magyarázható azzal is, hogy a pár tagjai - a társas természetú stratégiákon (pl. megosztják egymással a pozitív eseményt), illetve az éppen zajló folyamatról való kommunikáción keresztül - befolyásolják egymás kapacitását a pozitív élmények ízlelgetésére vonatkozóan. Következtetéseik továbbá azt mutatják, hogy a pár egyik tagja magasabb savoringről számol be, amikor párja nagyobb mértékben érintett a stresszteli esemény által. Értelmezésük szerint, ez felfogható egyfajta kiegészító copingként is, ahol a pár egyik tagja a negatív esemény által betöró gondolatok értelmezéséért felelős, míg a másik fél ebben a folyamatban a savoring által biztosít némi kikapcsolódást ez alól, visszaállítva a pozitív érzelmeket, hogy aztán közösen küzdjenek meg a problémával. Feltételezik, hogy ha az egyik fél kevésbé érintett a stresszor által, akkor a pozitív élmények fokozására fordított energiájának mértéke arányos lesz a partner által megélt distresszel. Ezen túlmenően a pár egyik tagjának nagyobb képessége a jelen idejú savoringre - amely vélhetóen ellensúlyozza az esemény negatív érzelmi következményeit és lehetőséget ad a párkapcsolat pozitív tapasztalásainak megélésére - magasabb kapcsolati elégedettséget jelez előre. Mindez persze fordítva is igaz lehet: azok a felek, akik elégedettebbek a kapcsolatukkal, nagyobb mértékben képesek a pozitív élmények megélésére nehéz életesemények idején. Ez utóbbi összefüggés hátterében a szerzők a pozitív érzelmeket találták közvetítőként. Így tehát a pozitív emóció a személyen belüli közvetítő a savoring és a kapcsolattal való elégedettség között, ahol mindez szintén fordítva is igaz lehet, tehát aki elégedettebb a kapcsolatával, annak magasabb a pozitívérzelem-szintje és szívesebben ízlelgeti a pozitív eseményeket. A vizsgálat eredményei felhívják a figyelmet arra, hogy az adaptív savoring a párkapcsolatot segítő folyamat, amely védőfaktorként funkcionálhat stresszel teli időszakban is (Samios \& Khatri, 2019).

Egy másik kutatás során hasonló eredményeket kaptak olyan diádoknál, ahol daganatos betegségben szenvedőket és az őket ápoló családtagokat 
vizsgálták. Itt a páciens a jelen pillanatban történő pozitív élmények élvezetére vonatkozó hite előrejelezte a családtagja pozitív érzelmi állapotát, míg a hozzátartozó jelenben történő savoringje pozitív irányú kapcsolatot mutatott a páciens élettel való elégedettségével. Az eredmények tehát ismételten megerősítették a pozitív élmények élvezetének fontosságát még a betegséggel árnyékolt helyzetekben is, amikor pozitív élmények esetlegesen ritkábban érik a párokat (Hou, Liang, Lau, \& Hall, 2019).

Mindezen túlmenóen, amennyiben a párok arra is képesek, hogy a negatív történések mellett a pozitív életeseményeket is megosszák a hozzájuk közelállóval, még több eróforrást kovácsolhatnak a keletkezó pozitív érzelmek ízlelgetésének erejéból és magasabb kapcsolati jóllétet élhetnek meg. A pozitív élmények fokozásának ezen formájánál fontos a megosztáson túl a fogadó fél reakciója is, amely adaptív esetben a pozitív élmény megélését tovább fokozhatja. Mellrákos betegek vizsgálatánál azt találták, hogy azokon a napokon, amikor a pár tagjai a nap legjobb eseményét megosztották egymással, mindkettőjüknél növekedett az aznap megélt intimitásszint, amelynek mértéke kapcsolatban állt a megosztást fogadó fél befogadásra való hajlandóságának mértékével is (Otto, Laurenceau, Siegel, \& Belcher, 2015).

A pozitív események ízlelgetésére való képesség azonban nem csak a beteg, illetve a kapcsolat számára fontos. A beteget ápoló hozzátartozó sokszor minden percét a páciens fizikai ellátásával és lelki támogatásával tölti. Mindez pszichés megterhelést jelent, aminek hatására akár pszichiátriai problémák is megjelenhetnek az ápolást végzők körében (Vanderwerker, Laff, Kadan-Lottick, McColl, \& Prigerson, 2005). Az ellátási feladatok terhével való megküzdés egyik módszere lehet, ha az ápoló családtag képes - mind fizikálisan, mind mentálisan - elszakadni az ápolási feladatoktól és átmenetileg valamilyen más, kikapcsolódást nyújtó tevékenységet végezni (pl. sétálni vagy kertészkedni). Ezen aktivitások során fontos a teljes kognitív kikapcsolás is, hiszen a distressz megéléséhez elegendő lehet csak rágondolni a nyomasztó terhekre.

Hou és munkatársai (2015) eredményei azt mutatták, hogy mind az eltávolodás az ápolási feladatoktól, mind a pozitív élmények ízlelgetése fordított irányú kapcsolatot mutat a gondozás közben megélt terhekkel, valamint az ápoló személy által tapasztalt szorongásos és depresszív tünetekkel. Az eltávolodás esetében ez a fordított kapcsolat csak alacsony, illetve közepes mértékú savoring esetén mutatkozott, míg az ízlelgetés attól függetlenül mutatta ezt az inverz összefüggést, hogy az ápoló mennyire volt képes leválni és eltávolodni az ellátáshoz kapcsolódó feladatoktól. Mindez a pozitív élmények megélésének prioritására hívja fel a figyelmet a daganatos betegek ápolásában felmerülő terhekhez való adaptációban. 


\section{Intervenciós lehetôségek}

A pozitív élmények feldolgozásának fokozására irányuló intervenciók (Bryant \& Veroff, 2007) alkalmazásának eredményességét - például a jóllét (Ho és mtsai, 2016a; 2016b; 2017), az élettel való elégedettség, a reziliencia (Salces-Cubero, Ramirez-Fernandez, \& Ortega-Martinez, 2018) és a napi boldogságszint növekedésében (Jose és mtsai, 2012), valamint a negatív érzelmek és depressziós tünetek csökkentésében (Hurley \& Kwon, 2013) számos kutatás eredménye támasztotta már alá. Ilyen intervenció lehet akár egy rövid séta is, amely során a külső szépségekre és annak tudatos, belső ízlelgetésére fordítjuk a figyelmünket. Az élményt tovább fokozhatjuk, ha a napi gyaloglás élményeit később írásban is összefoglaljuk, felelevenítve ezzel a tapasztaltakat. Az összetettebb gyakorlatok közé tartozik az úgynevezett mini-kirándulás, ahol pozitív aktivitásokról készítünk listát. Ezek között szerepelhet hosszabb, rövidebb, magányos vagy társas, spontán vagy tervezett elfoglaltság is. Mindezeket színes fotókkal és kollázs készítésével is kiegészíthetjük. Ezek után heti tervet alkotunk, amibe az összegyújtött elfoglaltságból minden napra beillesztünk egyet, amelyeket aztán meg is valósítunk. A hét zárásaként újra felidézzük az eseményeket, amelyek segítségével ismét átélhetjük a pozitív érzéseket (Bryant \& Veroff, 2007; Blickhan, 2015). Ebben a gyakorlatban jól megmutatkozik a savoring három idóbeli aspektusa. Hangsúlyt kap a tervezés, a jelen pillanat élvezete és az utólagos felidézés is.

Az úgynevezett mindfulness-to-meaning teória (Garland, Farb, Goldin, \& Fredrickson, 2015b) alapján a tudatos jelenlétnek - amely természetéból adódóan mentes az ítélkezéstól -, fontos szerepe lehet a figyelmi rendszer pozitív áthangolásában. Ez lehetővé teszi a páciens számára a betegség miatt beszúkült érzelmi és kognitív állapotból való kitörést és a környezetében lévő pozitív információk, események, érzelmek és gondolatok megtapasztalását. A betegséghez kapcsolódó érzelmek teljes spektrumának reakciómentes tudatosságával tehát a betegek szelektíven tudják fókuszálni a figyelmüket a betegség pozitív aspektusaira, miközben megállítják a negatív tapasztalatok ruminációját. A szelektív pozitív figyelem ezen folyamatán keresztül a betegek képesek átkeretezni a betegségről alkotott perspektívájukat, amely támogathatja a pozitív élmények fokozásának folyamatát is (Garland, 2016; Garland, \& Fredrickson, 2019).

Egy olyan tudatos jelenlét állapotának elsajátítása és gyakorlása, amely integrálja a pozitív információkra való fókuszálást, az újraértékelést és a pozitív élmények ízlelgetését és feldolgozását [pl. mindfulness-oriented recovery enhancement (Garland, Baker, Riquino, \& Priddy, 2020)], nemcsak a krónikus fájdalom esetében lehet hasznos, hanem egyéb betegségben szenvedő páciensek számára is (Garland \& Howard, 2013). 
Ugyan az onkopszichológia gazdag hazai terápiás repertoárja eddig nem tartalmazta a savoring stratégiák beépítését (Kovács és mtsai, 2017), azonban fontosnak tartjuk áttekinteni azokat a jó gyakorlatokat és kezdeményezéseket, amelyek megalapozhatják a savoring gyakorlati hasznosítását a páciensek és az óket gondozók támogatásában.

A hagyományosan ismert egyéni- és csoportterápiák mellett - amelyek az analitikusan orientálttól a kognitív-viselkedésterápiás fókuszúig sokfélék lehetnek - a hazai rákbeteg ellátásban jelen vannak a testi technikák (body work) körébe tartozó mozgásterápia és relaxáció (Riskó, 1999), valamint az autogén tréning (Kovácsné Török, 2017) is. A testi élmények tudatosítása (elsősorban a negatív testi állapotok módosítása) tehát bevett hozzáállásként segítheti a pozitív élményekre való koncentrálás testi megélést.

Jakubovits (2010) a hipnózis fontosságára hívja fel a figyelmet, amely hatások során az erőforrások támogatást kapnak és szinkronizálódnak, elősegítve a poszttraumás növekedést és a jobb lelki állapotot. Az Országos Onkológiai Intézet Radiológiai Diagnosztikai Osztályán végzett komplex pszichoszociális intervenciós programban 173 malignus emlődaganattal kezelt nőbeteg vett részt. A program fókuszában a megküzdés, a kognitív-érzelmi feldolgozás elősegítése, az életminőség javítása, a recidíva esélyének csökkentése, valamint a lelki és spirituális növekedés támogatása állt. A pácienseket például az egészségmagatartás fejlesztésével, az egészséges táplálkozás tanításával, a meditáció és a relaxáció elsajátításával, a szuggesztiók szerepének megismertetésével, valamint stresszkezeléssel és a negatív élmények átdolgozásával segítették. A hatékonyságvizsgálat eredményei a stressz, a szorongás, a depresszió és a fáradtság csökkenését mutatták az életminőség, a testkép, a személyes kontroll javulása, valamint a spirituális növekedés és poszttraumás növekedés mellett (Kovács és mtsai, 2012).

Egy hazai vizsgálat (Rohánszky, Prezenszki, Katonai, \& Konkolÿ Thege, 2014) eredményei szerint a Simonton-tréning (Simonton, MatthewsSimonton, \& Creighton, 1978) pozitív eredményeket hozott daganatos betegek pszichológiai jóllétének és életminőségének javulásában, illetve helyreállításában, többek között az észlelt stressz, a szorongás, a depresszió és a depresszív megküzdési stílus csökkenésének, valamint az életerő és önbiztató-figyelemelterelő megküzdés erősödésének tekintetében. A tréning relaxációra épül. Célja öngyógyitó imagináció elsajátítása, a betegséggel kapcsolatos félelmek és szorongások feldolgozása és a jövoóvel kapcsolatos pozitív célok megfogalmazása mellett, a rendszeres testmozgás és az egészséges táplálkozás is (Rohánszky és mtsai, 2014).

Az első magyar MBCR-módszer (mindfulness-based cancer recovery), vagyis a rákbetegséggel való megküzdést segítő tudatos jelenlét alapú program hatásvizsgálatának eredményei csökkent észlelt stressz-szintről, szo- 
rongásról és a depresszióról, depresszív- és bagatellizáló megküzdésről, valamint erősödő életerőről és optimizmusról számoltak be (Rohánszky, Berényi, Fridrik, \& Pusztafalvi, 2017).

A fent bemutatott eredmények felhívják a figyelmet arra, hogy a daganatos betegséggel küzdők terápiájának egészségpszichológiai aspektusában is fontos szerepet tölthetnek be az olyan intervenciók, amelyek a betegnek megtanítják a figyelmét a pozitív erőforrásokra irányítani (Garland, 2016), amelyek aztán lehetóvé teszik a pozitív élmények fokozásának folyamatából adódó pozitív érzelmi spirál elindítását és fenntartását. Az említett folyamatok fokozására irányuló intervenciók elsajátítása ezért lenne fontos úgy a betegek, mint a hozzátartozóik számára (Hou és mtsai, 2015). A pozitív élmények fokozására irányuló technikák kiterjesztése a családi kapcsolatokra a komplex terápiás folyamat segítőjévé válhatna (Hou és mtsai, 2019; Samios \& Khatri, 2019).

Korábban számos kritika érte a pozitív pszichológiát (Seligman \& Pawelski, 2003; Peterson \& Park, 2003), amely akár az általunk összefoglalt savoring konstruktumára is érvényesíthető lehet. A kritikusok egyszerúen „boldogságtannak” nevezték a tudományágat, amiért a negatívról nem vesz tudomást (Seligman \& Pawelski, 2003). Ma már tudjuk azonban, hogy ez nincs így. A pozitív pszichológia nem ignorálja a negatívat, csak új keretbe helyezi, ahol egyidejúleg a pozitív érzelmek és gondolatok gazdagító ereje is megjelenhet (Blickhan, 2015). A pozitív érzések és gondolatok fontossága - így a pozitív érzelmek élvezetének képessége is - éppen azokban az egzisztenciálisan fenyegető helyzetekben mutatkozhat meg leginkább, ahol a stresszt nem lehet figyelmen kívül hagyni, a problémák elól nem lehet elmenekülni, így a túléléshez és a jóllét megőrzéséhez minden erőforrásra szükség van. Amikor az emberi lét alapjaiban kérdőjeleződik meg - a tudatos jelenlét alapú intervenciók mellett - szükség van az időnként felvillanó pozitív élmények ízlelgetéséből származó jó érzések kiaknázására is. Erre a savoring mellett, azzal együtt alkalmazva lehetóséget nyújtanak olyan újonnan kifejlesztett terápiás intervenciók is, amelyek felismerve például a nevetés és a humor gyógyító hatását, célzottan alkalmazzák azt az onkológiai ellátásban (Bellert, 1989; Erdman, 1991; Ottawa, 1990; Penson és mtsai, 2005; Ripoll \& Casado, 2010).

\section{Megbeszélés}

A „kiszélesítés és bóvítés” teória (broaden-and-built theory) alapján a pozitív érzelmek alapvetően megváltoztatják az észlelésünket és lehetőséget adnak olyan védőbástyák felépítésére, amelyekben nem az érzelmek inten- 
zitásának, hanem megjelenési gyakoriságának van jelentősége (Fredrickson, 2001). A savoring, azaz a pozitív élmények ízlelgetésére való képességünk - az a folyamat, amelyet pozitív élményeink megtapasztalása révén keletkező jó érzéseink fokozásával érhetünk el - nem csak „hab a tortán” egy boldog élethez. Fő feladata akkor is megmutatkozik, amikor életünk hajójával viharos vizeken vagyunk kénytelenek evezni. Azokban az időszakokban, amikor nincs módunk intenzív pozitív élményeket átélni, akkor is képesek lehetünk figyelmünket gyakrabban fókuszálni a pozitív események által keltett érzésekre és ezek intenzitását növelni vagy időbeli hatásukat meghosszabbítani, akár a jelenben, a múltban vagy a jövőben zajlik az.

Azokban az életet veszélyeztetó állapotokban, amelyeket a kontrollvesztés és a halálfélelem árnyékol be - mint pl. a daganatos megbetegedések -, a betegségre való beszúkült állapotban alapvetó fontosságú lehet megtalálni azokat az erőforrásokat, amelyek meggátolják a beteg fizikai állapotának romlása mellett a mentális egészségének károsodását is. A pozitív élmények fokozására való képesség ezen állapotokban is képes csökkenteni a szorongásos tüneteket, növelni a pozitív érzelmi állapotot és az élettel való elégedettséget, valamint gyengíteni azt a hidat, amely a károsodott testi állapottól elvezethet a depresszióig (Garland, 2016; Hou és mtsai, 2016). Amennyiben a beteg képes a figyelmét a rendelkezésre álló védőfaktorokra irányítani, úgy a megbetegedés trauma helyett új perspektívát is hozhat az életébe (Chan és mtsai, 2011).

Fontos azonban meglátnunk azt is, hogy nem elég a beteget önmagában vizsgálnunk, hiszen kölcsönös együtthatásban mozog szociális környezetével. A beteget ért stressz kihat a párkapcsolatára és az ót ápoló családtagokra is, ami azonban azt is jelenti, hogy a felmerüló érzelmi distresszel való megküzdés közös feladattá is válhat, ahol a pozitív élmények élvezete például a párkapcsolatot segító folyamat lehet: növelheti a pozitív érzelmi állapotot, valamint az élettel és a párkapcsolattal való elégedettséget. Mindezek mellett a savoring a családtagok számára is segítséget nyújthat a betegség általi terhekhez való alkalmazkodásban, amelynek sikeressége szintén viszszahathat a személyközi kapcsolatra és a beteg állapotára is.

A tanulmányunkban ismertetett eredményekkel szeretnénk felhívni a figyelmet a pozitív élmények fokozásának jelentőségére és a hozzá kapcsolódó intervenciókban rejló újabb lehetőségekre a daganatos betegségek komplex terápiájában is, amelyek a hazai tapasztalatból felvillantott jó gyakorlatok palettáját is színesíthetik a jövőben. Mindezek mellett fontos azonban szem előtt tartanunk, hogy az említett beavatkozások hatékonysága még sok kutatást igényel, mind kultúrközi vizsgálatokban (Miyamoto \& Ma, 2011), mind pedig klinikai populáción, hogy az ellentmondásos eredmények (Hurley \& Kwon, 2012) is magyarázatot kaphassanak. 


\section{Irodalom}

Bellert, J.L. (1989). Humor, a therapeutic approach in Oncology nursing. Cancer Nursing, 12(2), 65-70.

Blickhan, D. (2015). Positive Psychologie. Ein Handbuch für die Praxis. Paderborn: Junfermann Verlag

Bryant, F.B. (1989). A 4-factor model of perceived control - Avoiding, coping, obtaining, and savoring. Journal of Personality, 57(4), 773-797.

Bryant, F.B. (2003). Savoring Beliefs Inventory (SBI): a scale for measuring beliefs about savouring. Journal of Mental Health, 12(2), 175-196.

Bryant, F.B., \& Veroff, J. (2007). Savoring. A new model of positive experience. New Jersey: Lawrence Erlbaum Associates

Carl, J. R., Soskin, D. P., Kerns, C., \& Barlow, D. H. (2013). Positive emotion regulation in emotional disorders: A theoretical review. Clinical Psychology Review, 33(3), 343-360.

Chadwick, E.D. (2012). The structure of adolescent and adult savoring and its relationship to feeling good and functioning well. Doctoral Dissertation. Wellington: Victoria University of Wellington

Chan, M.W.C., Ho, S.M.Y., Tedeschi, R.G., \& Leung, C.W.L. (2011). The valence of attentional bias and cancer-related rumination in posttraumatic stress and posttraumatic growth among women with breast cancer. Psycho-Oncology, 20, 544-552.

Cordova, M.J., Giese-Davis, J., Golant, M., Kronenwetter, C., Chang, V., \& Spiegel, D. (2007). Breast cancer as trauma: Posttraumatic stress and posttraumatic growth. Journal of Clinical Psychology in Medical Settings, 14, 308-319.

Erdman, L. (1991). Laughter therapy for patients with cancer. Oncology Nursing Forum, 18(8), 1359-1363.

Fredrickson, B.L. (2001). The role of positive emotions in positive psychology. The Broadenand-Build Theory of positive emotions. American Psychologist, 56(3), 218-226.

Friedman, L.C., Nelson, D.V., Baer, P.E., Lane, M., Smith, F.E., \& Dworkin, R.J. (1992). The relationship of dispositional optimism, daily life stress, and domestic environment to coping methods used by cancer patients. Journal of Behavioral Medicine, 15(2), 127-141.

Garland, E.L. (2016). Restructuring reward processing with Mindfulness-Oriented Recovery Enhancement: novel therapeutic mechanisms to remediate hedonic dysregulation in addiction, stress, and pain. Annals of the New York Academy of Sciences, 1373(1), 25-37.

Garland, E.L., Baker, A.K., Riquino, M.R., Priddy, S.E. (2020). Mindfulness-Oriented Recovery Enhancement. In: I. Ivtzan (Ed.), Handbook of mindfulness-based programmes (Chapter 26). New York: Routledge

Garland, E.L., Farb, N.A., Goldin, P.R., \& Fredrickson, B.L. (2015a). Mindfulness broadens awareness and builds eudaimonic meaning: A process model of mindful positive emotion regulation. Psychological Inquiry, 26(4), 293-314.

Garland, E.L., Farb, N.A., Goldin, P.R., \& Fredrickson, B.L. (2015b). The mindfulness-tomeaning theory: Extensions, applications, and challenges at the attention-appraisalemotion interface. Journal Psychological Inquiry, 26(4), 377-387.

Garland, E.L., \& Fredrickson, B.L. (2019). Positive psychological states in the arc from mindfulness to self-transcendence: extensions of the Mindfulness-to-Meaning Theory and applications to addiction and chronic pain treatment. Current Opinion in Psychology, 28, 184-191.

Garland, E.L., \& Howard, M.O. (2013). Mindfulness-oriented recovery enhancement reduces pain attentional bias in chronic pain patients. Psychotherapy and psychosomatics, 82(5), 311-318.

Garnefski, N., Kraaij, V., \& Spinhoven, P. (2001). Negative life events, cognitive emotion regulation and emotional problems. Personality and Individual Differences, 30, 1311-1327. 
Gross, J.J. (1998). The emerging field of emotion regulation: An integrative review. Review of General Psychology, 2(3), 271-299.

Hermann, J.L. (2003). Trauma és gyógyulás. Budapest: Háttér Kiadó - Kávé Kiadó - NANE Egyesület

Ho, H.C.Y., Mui, M., Wan, A., Ng, Y.-I., Stewart, S.M., Yew, C., et al. (2016a). Happy family kitchen: A community-based research for enhancing family communication and wellbeing in Hong Kong. Journal of Family Psychology, 30, 752-762.

Ho, H.C.Y., Mui, M., Wan, A., Ng, Y.-I., Stewart, S.M., Yew, C., et al. (2016b). Happy family kitchen II: A cluster randomized controlled trial of a community-based family intervention for enhancing family communication and well-being in Hong Kong. Frontiers in Psychology, 7, ArtID 638.

Ho, H.C.Y., Mui, M., Wan, A., Stewart, S.M., Yew, C., Lam, T.H., et al. (2017). Happy family kitchen: Behavioral outcomes of a brief community-based family intervention in Hong Kong. Journal of Child and Family Studies, 26, 2852-2864.

Horti, J., Riskó, Á. (Szerk.) (2017). Onkopszichológia a gyakorlatban. 2. online kiadás II./II. kötet. Letöltve: 2019. 11. 25-én: http:/ / mek.oszk.hu/16600/16625/pdf/16625_2.pdf

Hou, W.K., Lau, K.M., Ng, S.M., Cheng, A.C.K., Shum, T.C.Y., Cheng, S., et al. (2016). Savoring moderates the association between cancer-specific physical symptoms and depressive symptoms. Psycho-Oncology, 26(2), 231-238.

Hou, W.K., Lau, K.M., Ng, S.M., Lee, T.M.C., Cheung, H.Y.S., Shum, T.C.Y.S., et al. (2015). Psychological detachment and savoring in adaptation to cancer caregiving. PsychoOncology, 25(7), 839-847.

Hou, W.K., Liang, L., Lau, K.M., \& Hall, M. (2019). Savouring and psychological well-being in family dyads coping with cancer: An actor-partner interdependence model. European Journal of Cancer Care, 28(4), e13047.

Hurley, D.B., \& Kwon, P. (2012). Results of a study to increase savoring the moment: differential impact on positive and negative outcomes. Journal of Happiness Studies, 13, 579-588.

Hurley, D.B., \& Kwon, P. (2013). Savoring helps most when you have little: Interaction between savoring the moment and uplifts on positive affect and satisfaction with life. Journal of Happiness Studies, 14(4), 1261-1271.

Jakubovits, E. (2010). A hipnózis alkalmazásának indokai a daganatos betegek komplex terápiájában. Magyar Onkológia, 54, 153-160.

Jose, P.E., Lim, B.T., \& Bryant, F.B. (2012). Does savoring increase happiness? A daily diary study. The Journal of Positive Psychology, 7(3), 176-187.

Kovácsné Török, Zs. (2017). Szexuális zavarok. In: J. Horti, Á. Riskó (Szerk.), Onkopszichológia a gyakorlatban. 2. online kiadás II./II. kötet (370-378). Letöltve: 2019. 11. 25-én: http:/ / mek. oszk.hu/16600/16625/pdf/16625_2.pdf

Kovács, P., Koncz, Zs., Peti, J., Gődény, A., Horváth, D., Gerlinger, L., et al. (2017). Az onkopszichológiai rehabilitáció területei és kihívásai. Magyar Onkológia, 61, 284-291.

Kovács, Zs., Rigó, A., Kökönyei, Gy., Szabó, É., Kovács, D., Sebestyén, Á., et al. (2012). A hagyományos daganatterápiát kiegészítő komplex életmód és pszichoszociális intervenciós program - igen biztató eredményekkel. Magyar Onkológia, 56, 247-257.

Kruse, B.G. (1999). The lived experience of serenity: using Parse's Research Method. Nursing Science Quarterly, 12(2), 143-150.

Lazarus, R. S., \& Folkman, S. (1984). Stress, appraisal and coping. New York: Springer

Metin-Orta, I. (2018). The Savoring Beliefs Inventory: An adaptation study of the SBI in the Turkish cultural context. TPM-Testing, Psychometrics, Methodology in Applied Psychology, 25(1), 139-151.

Miyamoto, Y., \& Ma, X. (2011). Dampening or savoring positive emotions: A dialectical cultural script guides emotion regulation. Emotion, 11(6), 1346-1357. 
Monteiro S. de D.T., \& Marques Pinto, A. (2017). Reporting daily and critical events: Journalists' perceptions of coping and savouring strategies, and of organizational support. European Journal of Work and Organizational Psychology, 26(3), 468-480.

Nelson, D.L., \& Simmons, B.L. (2002). Health psychology and work stress: A more positive approach. In J.C. Quick, \& L.E. Tetrick (Eds.), Handbook of occupational health psychology (97-119). Washington DC: American Psychological Association

Ottawa, E.W. (1990). Lodges add humor to armamentarium in fight against cancer. Canadian Medical Association Journal, 5, 142-163.

Otto, A.K., Laurenceau, J-P., Siegel S.D., \& Belcher, A.J. (2015). Capitalizing on everyday positive events uniquely predicts daily intimacy and well-being in couples coping with breast cancer. Journal of Family Psychology, 29(1), 69-79.

Park, C.L., Edmondson, D., Fenster, J.R., \& Blank, T.O. (2008). Positive and negative health behavior changes in cancer survivors: a stress and coping perspective. Journal of Health Psychology, 13(8), 1198-1206.

Penson, R.T., Partridge, R.A., Rudd, P., Seiden, M.V., Nelson, J.E., Chabner, B.A., et al. (2005). Laughter: the best medicine? The Oncologist, 10, 651-660.

Peterson, C., \& Park, N. (2003). Positive psychology as the evenhanded positive psychologist views it. Psychological Inquiry, 14(2), 143-147.

Pohárnok, M., \& Lénárd, K. (2015). A trauma lélektana. In: E. Cs. Kiss, \& H. Sz. Makó (Szerk.), Gyász, krízis, trauma és a megküzdés lélektana (221-234). Pécs: Pro Pannónia Kiadó

Quoidbach, J., Berry, E.V., Hansenne, M., \& Mikolajczak, M. (2010). Positive emotion regulation and well-being: Comparing the impact of eight savoring and dampening strategies. Personality and Individual Differences, 49(5), 368-373.

Ripoll, R. M., \& Casado, I. Q. (2010). Laughter and positive therapies: modern approach and practical use in medicine. Revista de Psiquiatría y Salud Mental (English Edition), 3(1), 27-34.

Riskó, Á. (1999). Bevezetés az onkopszichológiába (jegyzet). Budapest: Animula

Robles, R., Fresan, A., Zuniga, T., Zaldivar, J., Santana, O., De la Cruz, D., et al. (2011). Evaluation of positive psychological constructs in Hispanic population: The case of beliefs about enjoying life. Anales de Psicología, 27(1), 58-64.

Rohánszky, M., Berényi, K., Fridrik, D., \& Pusztafalvi, H. (2017). Éber, tudatos figyelemre épülő, a rákbetegséggel való megküzdést segítő program (MBCR) hatásvizsgálata magyar rákbetegek körében. Orvosi Hetilap, 158(33), 1293-1301.

Rohánszky, M., Prezenszki, Zs., Katonai, R., \& Konkolÿ Thege, B. (2014). Mit gyógyít a gyógyító képzelet? A Simonton-módszer hatékonysága magyar daganatos betegek körében. Magyar Pszichológiai Szemle, 69(4), 474-760.

Salces-Cubero, I.M., Ramirez-Fernandez, E., \& Ortega-Martinez, A.R. (2018). Strengths in older adults: differential effect of savoring, gratitude and optimism on well-being. Aging and Mental Health, 23(8), 1017-1024.

Samios, C., \& Khatri, V. (2019). When times get tough: Savoring and relationship satisfaction in couples coping with a stressful life event. Anxiety Stress Coping, 32(2), 125-140.

Seligman, M. E. P., Pawelski, J. O. (2003). Positive Psychology: FAQs. Psychological Inquiry, 14(2), 159-163.

Simonton, O.C., Matthews-Simonton, S., \& Creighton, J. (1978). Getting well again: A stepbystep, self-help guide to overcoming cancer for patients and their families. Los Angeles: JP Tarcher Inc.

Skott, C. (2002). Expressive metaphors in cancer narratives. Cancer Nursing, 25(3), 230-235. Smith, J.L., \& Hollinger-Smith, L. (2015). Savoring, resilience, and psychological well-being in older adults. Aging and Mental Health, 19(3), 192-200.

Sytine, A.I., Britt, T.W., Pury, C.L.S., \& Rosopa, P.J. (2018). Savouring as a moderator of the combat exposure-mental health symptoms relationship. Stress and Health, 34(4), 582-588. 
Szondy, M., Martos, T., Szabó-Bartha, A., \& Pünkösty, M. (2014). A Rövidített Pozitív Élmények Feldolgozási Módjai Skála magyar változatának reliabilitás-és validitásvizsgálata. Mentálhigiéné és Pszichoszomatika, 15, 305-316.

Tedeschi, R.G., \& Calhoun, L,G. (2004). Posttraumatic growth: Conceptual foundations and empirical evidence. Psychological inquiry, 15(1), 1-18.

Tugade, M.M., \& Fredrickson, B.L. (2007). Regulation of positive emotions: Emotion regulation strategies that promote resilience. Journal of Happiness Studies, 8(3), 311-333.

Vajda, D., \& Rózsa, S. (2018). Diádikus adatelemzés: Actor-Partner Interdependence Model. Alkalmazott Pszichológia, 18(3), 99-123.

Vanderwerker, L.C., Laff, R.E., Kadan-Lottick, N.S., McColl, S., \& Prigerson, H.G. (2005). Psychiatric disorders and mental health service use among caregivers of advanced cancer patients. Journal of Clinical Psychology, 23(28), 6899-6907.

Wilson, C.A., \& Saklofske, D.H. (2018). The relationship between trait emotional intelligence, resiliency, and mental health in older adults: the mediating role of savouring. Aging and Mental Health, 22(5), 646-654.

Zsigmond, O., Rigó, A., \& Bányai, É. (2017). A daganatos betegségek Janus arca: a poszttraumás növekedés jelensége. Mentálhigiéné és Pszichoszomatika, 18(2), 149-170.

\section{A szerzók munkamegosztása}

A kézirat megírásában és az irodalom összeállításában mindkét szerző részt vett. P. V. A.: nemzetközi szakirodalom gyújtése, elemzése, szövegezése. F. L. ZS.: nemzetközi szakirodalom gyưjtése, kézirat szövegezése, lektorálása és szerkesztése.

\section{Nyilatkozat érdekütközésról}

A szerzők ezúton kijelentik, hogy esetükben nem állnak fenn érdekütközések. 


\section{The importance of savoring in the complex therapy of cancer patients \\ PÁLINKÓNÉ VÁRSZEGI, ANDREA - F. LASSÚ, ZSUZSA}

By reviewing the results of recent researches we aimed to highlight the importance of savoring in the complex therapy of cancer. These results show that savoring is not only an essential component of a happy life, but it can also be an important resource in stressful periods and serious illness as the life-threatening cancer, both for the patient and for his relatives and caregivers. Savoring can reduce, among others, illness-related anxiety, depression, emotional distress and increase positive emotional and life satisfaction as well as relationship satisfaction. The mentioned results, as well as the potential of savoring interventions, may represent a new approach in the field of Hungarian oncopsychological care as well.

Keywords: savoring, positive emotions, cancer, intervention

A cikk a Creative Commons Attribution 4.0 International License (https:/ / creativecommons.org/ licenses/by/4.0/) feltételei szerint publikált Open Access közlemény, melynek szellemében a cikk bármilyen médiumban szabadon felhasználható, megosztható és újraközölhető, feltéve, hogy az eredeti szerző és a közlés helye, illetve a CC License linkje és az esetlegesen végrehajtott módosítások feltüntetésre kerülnek. (SID_1) 